\title{
Resistance of Pepper to Phytophthora Crown, Root, and Fruit Rot Is Affected by Isolate Virulence
}

J. M. Foster, former Graduate Research Assistant, and M. K. Hausbeck, Professor, Department of Plant Pathology, Michigan State University, East Lansing 48824

\begin{abstract}
Foster, J. M., and Hausbeck, M. K. 2010. Resistance of pepper to Phytophthora crown, root, and fruit rot is affected by isolate virulence. Plant Dis. 94:24-30.

Greenhouse and laboratory experiments were conducted to determine the virulence of four Phytophthora capsici isolates from Michigan to 31 bell and hot pepper cultivars and breeding lines. Resistance to crown and root rot was assessed following the inoculation of soilless media with $P$. capsici-infested millet seed. In a detached fruit assay, fruit rot resistance was evaluated following inoculation with zoospore suspensions of $1.75 \times 10^{6}$ zoospores $/ \mathrm{ml}$. The four isolates differed in virulence to pepper lines screened for crown and root rot resistance and were considered to be four different physiological races. The pepper lines CM334, NY07-8001, NY07-8006, and NY07-8007 were resistant to the isolates tested. None of the commercial cultivars were resistant to $P$. capsici isolate 12889 , but several cultivars were resistant to the other isolates screened. The isolates varied in their ability to cause infection on the fruits of the different cultivars. Overall, pepper fruit were more susceptible to $P$. capsici than the roots and crowns. Management of Phytophthora crown and root rot of pepper can be improved through the use of resistant cultivars. However, since isolate virulence affects resistance, cultivar resistance will need to be utilized on a local scale accordingly.
\end{abstract}

Phytophthora capsici L. is a soilborne pathogen that was first identified on pepper (Capsicum annuum L.) in New Mexico in 1922 (18). Since then, more than 50 plant species, including many Solanaceous and Cucurbitaceous vegetable crops, have been identified as hosts worldwide $(7,9,13,22)$. In 2008, Michigan producers grew over 25,000 ha of vegetables susceptible to $P$. capsici, including 730 ha of peppers (2). $P$. capsici may infect the roots, crown, stem, leaves, and/or fruits of pepper $(18,33)$. The pathogen may enter the roots or base of the stem (25). Eventually, watersoaked lesions develop that rapidly progress to cause girdling of the stem, and plant wilting and death (25). Control of Phytophthora crown and root rot requires the use of cultural practices, fungicides, fumigants, and genetically resistant varieties in an integrated program $(6,13,25)$.

Several commercial bell pepper cultivars are tolerant to $P$. capsici, but no cultivar provides resistance to a wide range of isolates $(11,19)$. Peppers are considered tolerant to $P$. capsici if the plant is able to sustain infection without dying or crop loss (1). The cultivars Paladin (Syngenta Seeds Inc., Boise, ID), Aristotle (Seminis Vege-

Corresponding author: M. K. Hausbeck

E-mail: hausbec1@msu.edu

Accepted for publication 2 October 2009.

doi:10.1094/PDIS-94-1-0024

(C) 2010 The American Phytopathological Society table Seeds, St. Louis, MO), Declaration (Harris Moran Seed Company, Modesto, CA), Karisma (Harris Moran Seed Company), Intruder (Syngenta Seeds Inc.), and Revolution (Harris Moran Seed Company) are regarded as resistant or tolerant to $P$. capsici by seed distributors. Growers are reluctant to use resistant or tolerant cultivars because of a perceived increase in incidence of silvering (the separation of the fruit cuticle from the epidermis) (37), and because of poor fruit shape (24), both of which result in unmarketable fruit.

The pepper line Criollo de Morales 334 (CM334), a landrace with small Serranotype fruit, has demonstrated resistance to a variety of $P$. capsici isolates from different hosts and geographic regions $(10,11,29$, $32,35)$. CM334 is the primary source of root rot resistance currently used in pepper breeding programs $(10,32)$. The inheritance of resistance in CM334 is not completely understood. Guerrero-Moreno and Laborde found two recessive genes that provided resistance (12), and later Gil Ortega et al. proposed a three-gene, multiallelic system as the source of resistance (10). Initial quantitative trait loci (QTL) analysis proposed that three QTLs were responsible for resistance; other studies confirmed a major QTL, reported to span the entire length of chromosome 5 $(16,17,20)$. In 2003, six regions on chromosomes $4,5,6,11$, and 12 were determined to be involved in some part of resistance (32). When using CM334 as the source of $P$. capsici resistance, the resulting pepper lines may only contain some of the QTLs that provide resistance, and therefore remain susceptible to some isolates. As a result, a bell pepper with levels of resistance comparable to that of CM334 with desired horticultural characteristics has not been developed $(31,32)$.

Recent studies have indicated that physiological races exist in the pepper- $P$. capsici pathosystem $(11,19,29,30)$, which implies that pepper breeders need to test breeding lines against a wide range of $P$. capsici isolates. Furthermore, research has suggested that different genetic mechanisms may be responsible for resistance to root rot, stem blight, and foliar blight of pepper $(3,28)$.

In Michigan, symptoms on aerial plant parts, including leaf blight and fruit rot, are observed in the field less frequently than root and crown rot symptoms (13). Hence, growers in Michigan would benefit most from a cultivar that is primarily resistant to root and crown rot and stem blight. Furthermore, it may be easier to protect against foliar and fruit disease symptoms with fungicide sprays than against crown and root rot since most fungicides are only registered for foliar applications. To our knowledge, Michigan isolates have not been included in previous screens of pepper lines for root and crown resistance to $P$. capsici. In addition, virulence of $P$. capsici isolates from Michigan on pepper cultivars and breeding lines has not been tested and is relatively unknown. The objectives of this study were to evaluate cultivars and breeding lines of pepper for resistance to Phytophthora crown and root rot using isolates of $P$. capsici from three different hosts from Michigan and to measure virulence of three of these isolates on pepper fruit.

\section{MATERIALS AND METHODS}

$P$. capsici isolate selection and inoculum preparation. Isolates of $P$. capsici obtained from infected plants in Michigan were selected from the long-term culture collection of Mary Hausbeck at Michigan State University (MSU). Isolates were classified according to mating type (MT) and sensitivity to mefenoxam, an oomycete-specific fungicide. The isolates OP97 (A1 MT) and SP98 (A2 MT) are sensitive to mefenoxam and were originally isolated from pickling cucumber and pumpkin, respectively. The isolates 12889 (A1 MT) and SFF3 (A2 MT) are insensitive to mefenoxam and were isolated from pepper and pickling cucumber, respectively. 
Isolates were grown on unclarified $\mathrm{V} 8$ agar (UCV8, $16 \mathrm{~g}$ of agar, $3 \mathrm{~g}$ of $\mathrm{CaCO}_{3}$, $160 \mathrm{ml}$ of $\mathrm{V} 8$ juice, and $840 \mathrm{ml}$ of distilled water) under constant fluorescent light at room temperature $\left(21 \pm 2^{\circ} \mathrm{C}\right)$ for 7 days. Millet seed inoculum was prepared according to the method of Quesada-Ocampo et al. (22). Isolates OP97, SP98, and 12889 were used to screen the harvested fruit for resistance. Zoospore inoculum was prepared by flooding actively sporulating cultures with sterile distilled water and incubating at $4{ }^{\circ} \mathrm{C}$ for $1 \mathrm{~h}$ followed by $30 \mathrm{~min}$ at room temperature to initiate zoospore release. The concentration of the zoospore suspension was estimated using a hemacytometer and adjusted to $1.75 \times 10^{6}$ zoospores $/ \mathrm{ml}$.

Phytophthora root and crown rot screen. Two experiments were conducted to screen commercial cultivars and breeding lines for resistance to Phytophthora root and crown rot. Experiments included 28 or 14 pepper lines, respectively, and nine commercially available cultivars (Alliance, Aristotle, Brigadier, Camelot, Declaration, Paladin, Red Knight, Revolution, and Snapper). Seeds were sown into 72cell flats filled with potting media (BACCTO Professional Planting Mix, Michigan Peat Company, Houston, TX) and placed into a greenhouse with a 14-h photoperiod. When seedlings developed three or four true leaves, they were transplanted into 1.5-liter pots filled with potting media (described above) that were arranged in a complete randomized design in a greenhouse with a 14-h photoperiod at MSU's Horticulture Teaching and Research Center, East Lansing, MI. The average air temperature recorded in the greenhouse experiments was $19.4^{\circ} \mathrm{C}$ (minimum $1.0^{\circ} \mathrm{C}$, maximum $39.7^{\circ} \mathrm{C}$ ), and the mean relative humidity was $62.6 \%$ (minimum $20.7 \%$, maximum $96.2 \%$ ).

All isolates and a sterile millet control treatment were replicated eight times for each pepper line that was screened, and one experimental unit consisted of one plant. The potting medium was infested with $1 \mathrm{~g}$ of infected millet seed per plant, which was inserted into the media directly adjacent to the pepper seedling's root mass 1 day after transplanting. The plants were watered daily to maintain adequate moisture for plant growth and disease development. In the first 6 weeks of growth, the pots were fertilized weekly with Peter's (Scott's Company, Marysville, OH) 20-2020 soluble fertilizer at $200 \mathrm{ppm}$. For the remainder of the experiment, the pots were fertilized three times per week with the same solution. Irrigation water was amended with phosphoric acid at $132 \mathrm{ppm}$ weekly to maintain the media $\mathrm{pH}$ at approximately 6.0 to 6.5 . The $\mathrm{pH}$ was checked monthly by collecting random media samples and using a $\mathrm{pH}$ meter (Hanna Instruments, Woonsocket, RI).

Severity of Phytophthora crown and root rot was evaluated every 2 days until fruit were harvested (average 83 days postinoculation). Plants were rated on a 1 to 5 scale $(1=$ healthy, $2=$ minor wilting, $3=$ moderate wilting, $4=$ severe wilting, 5 $=$ plant death) adapted from Glosier et al. (11). The area under the disease progress curve (AUDPC) was calculated by inserting the disease score into the equation by Shaner and Finney (27) to describe the cumulative plant infection throughout the growing period. Approximately $10 \%$ of the symptomatic plants were returned to the laboratory to isolate and verify the pathogen. The root and crown area were rinsed with deionized water and surface-sterilized using a $70 \%$ ethanol solution. Three sections of root and crown tissue were excised and plated onto UCV8 plates amended with $25 \mathrm{ppm}$ of benomyl, $100 \mathrm{ppm}$ of ampicillin, $30 \mathrm{ppm}$ of rifampicin, and 100 ppm of pentachloronitrobenzene (BARP). Plates were incubated at room temperature under constant fluorescent lighting for 3 days and observed at $\times 200$ using a compound microscope to confirm P. capsici using morphological characteristics according to the Phytophthora spp. key by Waterhouse (36). Hyphal-tips of $P$. capsici cultures were transferred onto new BARP-amended UCV8 agar plates. After 7 days, each resulting isolate was screened for mefenoxam sensitivity and mating type to verify the isolate phenotype (15). Each experiment was conducted twice.

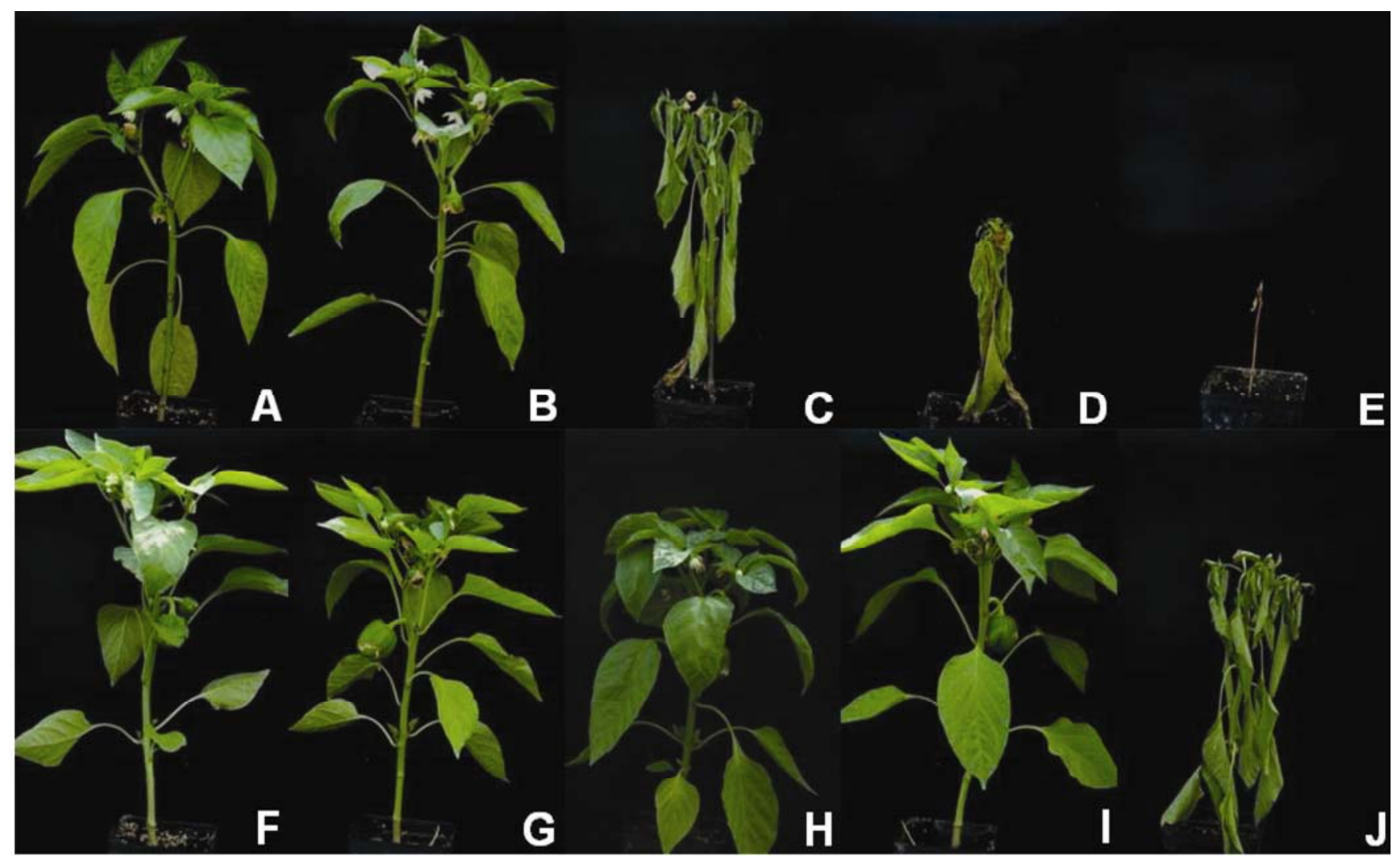

Fig. 1. Symptoms produced on cultivars A to E, Red Knight and $\mathbf{F}$ to J, Paladin 6 weeks postinoculation with $1 \mathrm{~g}$ of millet seed inoculum prepared with one of four isolates of Phytophthora capsici: B and G, SP98; C and H, SFF3; D and I, OP97; and E and J, 12889. Controls, A and F, were inoculated with sterile millet seed. 
Phytophthora fruit rot screen. In the pepper fruits were harvested when the average fruit diameter was between 7 and $10 \mathrm{~cm}$; these were stored for a maximum of 5 days at $2^{\circ} \mathrm{C}$. Prior to inoculation, fruits were returned to room temperature, surface-disinfested with a $10 \%$ bleach $(6.15 \% \mathrm{NaClO})$ solution for $10 \mathrm{~min}$, and rinsed with distilled water. Fruits were moist paper toweling was placed into each chamber to maintain humidity at $\sim 100 \%$. A $10-\mu \mathrm{l}$ drop of the zoospore suspension was placed onto the surface of each fruit. Chambers were sealed with plastic film and maintained at room temperature $(21 \pm$ $2{ }^{\circ} \mathrm{C}$ ). The fruits were incubated in the dark for $60 \mathrm{~h}$, followed by $24 \mathrm{~h}$ under constant fluorescent lighting to allow for pathogen sporulation.

The lesion area that developed on the fruits was estimated by measuring the diameter of water-soaked tissue, pathogen sporulation, and/or mycelia growth. To estimate the density of sporulation, a tape mount was prepared from an area of the lesion with pathogen sporulation. The average number of sporangia in five fields of view at $\times 400$ was extrapolated to estimate the number of sporangia per lesion. The experiment was replicated two times.

Statistical analysis. Mean AUDPC values and mean disease severity ratings were subjected to analysis of variance (ANOVA) using the PROC MIXED procedure of SAS v 9.1 (SAS Institute Inc., Cary, NC). Fisher's protected LSD was used for separation of means when effects were found to be statistically significant in ANOVA analysis $(P=0.05)$. AUDPC data from both crown and root rot experiments were $\log$ transformed prior to LSD analysis to satisfy assumptions of normality. A pepper line was considered resistant to the isolate if it received an average disease score (DS) $<2$, adapted from previously described methods $(5,11)$. To evaluate the lesion area data, all asymptomatic fruits (no lesions) were removed from the analysis. Fruit area measurements were square-root transformed to satisfy normality assumptions of first crown and root rot experiment, the placed into sterile humidity chambers, and

the test. Satterthwaite's approximation (SAS Institute) was used to account for the differences in number of experimental units in all fruit data analyses. Noninoculated control plants and fruits were removed from the data set prior to statistical analysis.

\section{RESULTS}

Phytophthora root and crown rot screen. Susceptible pepper plants exhibited crown rot and stem lesions followed by wilting and death when inoculated with P. capsici-infested millet seed containing one of the Michigan isolates (Fig. 1). All isolates of $P$. capsici obtained from inoculated plants were confirmed to have the same phenotype as the isolate used for inoculum (data not shown). None of the noninoculated control plants showed disease symptoms. Significant differences $(P$ $\leq 0.05$ ) were found among AUDPC values calculated for the isolates and pepper lines, but the interaction was not significant.

In both experiments, the mean AUDPC values were statistically different for $P$. capsici isolates; isolate 12889 was more virulent than OP97, and both were more virulent than SP98 and SFF3 (Fig. 1, Table 1). All of the pepper lines tested except for CM334, NY07-8001, NY07-8006, and NY07-8007 were susceptible to isolate 12889 (Table 2). In the first experiment investigating root and crown rot, 19 of the 26 pepper lines tested were susceptible to the pickling cucumber isolate OP97 (DS $\geq$ 2 ), and 6 of the 14 pepper lines tested in the second experiment were susceptible to this isolate. No pepper lines were susceptible to SP98 in the first experiment (DS < 2 ), and only one was susceptible in the second experiment (DS $=2.0$ ). One pepper line was susceptible to SFF3 in the first experiment (DS $=2.1$ ), and all were asymptomatic in the second experiment (DS <2).

Four of the nine cultivars showed different disease responses to the $P$. capsici isolates in the two experiments (Table 2). In the first experiment, Aristotle, Declaration, and Red Knight were susceptible to isolates 12889 (DS = 5.0) and OP97 (DS = 2.1 to 4.8$)$, but resistant to SP98 (DS $=1.1$

Table 1. Mean area under the disease progress curve (AUDPC) values for Phytophthora capsici isolates causing crown and root rot symptoms in 27 pepper lines (experiment 1) and 14 pepper lines (experiment 2)

\begin{tabular}{llccrc}
\hline & & & \multicolumn{2}{c}{ AUDPC $^{\mathbf{x}}$} \\
\cline { 5 - 6 } Isolate & Host & MT $^{\mathbf{y}}$ & MS $^{\mathbf{y}}$ & Experiment 1 $^{\mathbf{z}}$ & Experiment 2 \\
\hline SFF3 & Pickling cucumber & A2 & $\mathrm{I}$ & $94 \mathrm{a}$ & $97 \mathrm{a}$ \\
SP98 & Pumpkin & A2 & $\mathrm{S}$ & $95 \mathrm{a}$ & $100 \mathrm{a}$ \\
OP97 & Pickling cucumber & A1 & $\mathrm{S}$ & $186 \mathrm{~b}$ & $135 \mathrm{~b}$ \\
12889 & Bell pepper & A1 & I & $308 \mathrm{c}$ & $276 \mathrm{c}$ \\
\hline
\end{tabular}

${ }^{x}$ AUDPC was calculated by using the disease score determined every 2 days using a 1 to 5 rating scale ( 1 = healthy, 2 = minor wilting, 3 = moderate wilting, 4 = severe wilting, 5 = plant death).

y Isolate phenotypes are indicated by mating type (MT) and mefenoxam sensitivity (MS, I = insensitive, $\mathrm{S}=$ sensitive).

${ }^{\mathrm{z}}$ Column means with a letter in common are not statistically different according to Fisher's LSD $(P=$ $0.05)$. to 1.9 ) and SFF3 (DS $=1.1$ to 1.8$)$. In the same experiment, Snapper was susceptible to isolates 12889 (DS = 5.0), OP97 (DS = 5.0), and SFF3 (DS = 2.1), but resistant to SP98 (DS $=1.9$ ). In the second experiment, Aristotle and Declaration were susceptible to only 12889 (DS $\leq 4.3$ ) and resistant to OP97 (DS $\leq 1.5)$, SP98 (DS $\leq$ 1.3), and SFF3 (DS = 1.0). Red Knight was resistant only to SFF3 (DS $=1.8$ ), and Snapper was resistant to SP98 (DS $=1.3$ ) and SFF3 (DS = 1.3).

When data from the nine cultivars were combined from both experiments, Aristotle and Declaration were only susceptible to 12889 (DS $\leq 4.6$ ), and Red Knight and Snapper were susceptible to 12889 (DS $\leq$ 4.9) and OP97 (DS = 4.3). Plant death (\%) caused by isolates 12889 and OP97 progressed rapidly over time compared to SP98 and SFF3 on Red Knight (Fig. 2). Isolate 12889 caused more plant death than OP97, SP98, and SFF3 on Paladin.

Phytophthora fruit rot screen. Harvested pepper fruits did not have any apparent disease symptoms (rot, watersoaking) or pathogen signs (mycelial growth or pathogen sporulation). None of the fruit inoculated with sterile distilled water developed disease symptoms. Lesions on inoculated fruits expanded from the point of inoculation and were elliptical, with elongation from the stem end to blossom end of the fruit (Fig. 3). While some lesions displayed water-soaking only, other lesions exhibited pathogen mycelial growth and/or sporulation at the time of evaluation (84 h postinoculation, Fig. 4). Fruit infection incidence (\%) was least for fruit inoculated with isolate SP98 and greatest for isolate 12889, the latter of which caused the greatest percentage of fruit with water-soaked lesions, pathogen mycelial growth, and pathogen sporulation. Inoculations with isolate SP98 resulted in the lowest incidence of fruit with water-soaked lesions and pathogen mycelial growth, and fruit inoculated with isolate OP97 resulted in the smallest percentage of fruit with pathogen sporulation. When isolates 12889 and OP97 were used, more pepper lines supported pathogen sporulation on fruits than when isolate SP98 was used as inoculum (data not shown).

Isolate 12889 produced water-soaked lesions that were larger than those caused by OP97, but similar to SP98 (LSD, $P=$ 0.05 ) (Fig. 5). No statistical differences in area with pathogen mycelial growth or sporulation were noted among the three isolates when subjected to Fisher's protected LSD analyses. The density of sporangia in lesions with the sporulating pathogen was greater for isolates OP97 and SP98 than for isolate 12889 (LSD, $P$ $=0.05)$. Statistical differences among cultivars were not noted for lesion area and sporangial density on infected fruit (data not shown). 


\section{DISCUSSION}

Pepper producers in Michigan would benefit from a cultivar that is resistant to Phytophthora crown and root rot. In our study, the susceptibility of pepper lines to Phytophthora root and crown rot differed significantly when four Michigan isolates of $P$. capsici were used. None of the com- mercial cultivars included in our screen had resistance to the highly virulent isolate 12889, but several cultivars were resistant to the three other isolates. In our study, the breeding lines CM334, NY078001, NY07-8006, and NY07-8007 were resistant to all four isolates, and are the most promising sources of resistance for future breeding efforts and commercial use.

Several methods have been developed to screen pepper seedlings for resistance to Phytophthora root and crown rot $(5,11,19,29)$. The chi-squared method has been used to make comparisons with a standard resistant pepper, such as CM334,

Table 2. Pepper lines screened for crown and root rot resistance to four Michigan Phytophthora capsici isolates obtained from pepper (12889), pickling cucumber (OP97, SFF3), and pumpkin (SP98)

\begin{tabular}{|c|c|c|c|c|c|c|c|c|c|c|c|c|}
\hline \multirow[b]{2}{*}{ Pepper line $\mathrm{e}^{\mathrm{q}, \mathrm{r}}$} & \multicolumn{4}{|c|}{ Disease response $^{o}$} & \multicolumn{4}{|c|}{ AUDPCp } & \multicolumn{4}{|c|}{ Death $(\%)$} \\
\hline & 12889 & OP97 & SP98 & SFF3 & 12889 & OP97 & SP98 & SFF3 & 12889 & OP97 & SP98 & SFF3 \\
\hline \multicolumn{13}{|l|}{ Experiment 1} \\
\hline $9925776^{\mathrm{s}}$ & $\mathrm{S}$ & $\mathrm{S}$ & $\mathrm{R}$ & $\mathrm{R}$ & 339 & 202 & 100 & 91 & 100 & 63 & 13 & 6 \\
\hline $9931126^{\mathrm{s}}$ & $\mathrm{S}$ & $\mathrm{R}$ & $\mathrm{R}$ & $\mathrm{R}$ & 239 & 111 & 87 & 93 & 81 & 25 & 0 & 13 \\
\hline $9941819^{s}$ & $\mathrm{~S}$ & $\mathrm{~S}$ & $\mathrm{R}$ & $\mathrm{R}$ & 335 & 201 & 86 & 86 & 100 & 69 & 0 & 0 \\
\hline $9943084^{\mathrm{s}}$ & $\mathrm{S}$ & $\mathrm{S}$ & $\mathrm{R}$ & $\mathrm{R}$ & 330 & 171 & 107 & 86 & 100 & 44 & 13 & 0 \\
\hline $9943095^{\mathrm{s}}$ & $\mathrm{S}$ & $\mathrm{S}$ & $\mathrm{R}$ & $\mathrm{R}$ & 358 & 306 & 125 & 87 & 100 & 94 & 19 & 0 \\
\hline Alliance ${ }^{t}$ & $\mathrm{~S}$ & $\mathrm{~S}$ & $\mathrm{R}$ & $\mathrm{R}$ & 363 & 283 & 101 & 94 & 100 & 94 & 19 & 6 \\
\hline \multicolumn{13}{|l|}{$(\text { nonpelleted })^{\mathrm{s}}$} \\
\hline Aristotle (pelleted) $)^{\mathrm{s}}$ & $\mathrm{S}$ & $\mathrm{S}$ & $\mathrm{R}$ & $\mathrm{R}$ & 354 & 148 & 89 & 96 & 100 & 31 & 0 & 13 \\
\hline Brigadier $^{\mathrm{u}}$ & $\mathrm{S}$ & $\mathrm{S}$ & $\mathrm{R}$ & $\mathrm{R}$ & 362 & 301 & 118 & 99 & 100 & 94 & 25 & 13 \\
\hline Camelot $^{\mathrm{s}}$ & $\mathrm{S}$ & $\mathrm{S}$ & $\mathrm{R}$ & $\mathrm{R}$ & 361 & 259 & 94 & 108 & 100 & 94 & 13 & 19 \\
\hline Declaration $^{\mathrm{t}}$ & $\mathrm{S}$ & $\mathrm{S}$ & $\mathrm{R}$ & $\mathrm{R}$ & 305 & 119 & 101 & 86 & 100 & 25 & 19 & 0 \\
\hline Paladin ${ }^{\mathrm{u}}$ & $\mathrm{S}$ & $\mathrm{R}$ & $\mathrm{R}$ & $\mathrm{R}$ & 200 & 105 & 87 & 87 & 63 & 6 & 0 & 0 \\
\hline Plato $^{\mathrm{s}}$ & $\mathrm{S}$ & $\mathrm{S}$ & $\mathrm{R}$ & $\mathrm{R}$ & 347 & 252 & 95 & 104 & 100 & 81 & 13 & 6 \\
\hline PRO3-13×14R-4 ${ }^{v}$ & $\mathrm{~S}$ & $\mathrm{R}$ & $\mathrm{R}$ & $\mathrm{R}$ & 227 & 90 & 88 & 90 & 63 & 0 & 6 & 6 \\
\hline PRO3-15×16R-5 & $\mathrm{S}$ & $\mathrm{R}$ & $\mathrm{R}$ & $\mathrm{R}$ & 136 & 93 & 87 & 95 & 38 & 6 & 0 & 13 \\
\hline PRO4T-11×12v & $\mathrm{S}$ & $\mathrm{S}$ & $\mathrm{R}$ & $\mathrm{R}$ & 315 & 130 & 91 & 90 & 100 & 25 & 6 & 6 \\
\hline PRO5-C71 $\times 72^{v}$ & $\mathrm{~S}$ & $\mathrm{~S}$ & $\mathrm{R}$ & $\mathrm{R}$ & 321 & 159 & 86 & 86 & 100 & 31 & 0 & 0 \\
\hline PRO5-C $81 \times 82^{v}$ & $\mathrm{~S}$ & $\mathrm{R}$ & $\mathrm{R}$ & $\mathrm{R}$ & 225 & 92 & 86 & 88 & 81 & 13 & 0 & 6 \\
\hline PRO5-C $85 \times 86^{\mathrm{v}}$ & $\mathrm{S}$ & $\mathrm{S}$ & $\mathrm{R}$ & $\mathrm{R}$ & 329 & 143 & 96 & 88 & 100 & 56 & 6 & 6 \\
\hline PRO5-C $87 \times 88^{v}$ & $\mathrm{~S}$ & $\mathrm{~S}$ & $\mathrm{R}$ & $\mathrm{R}$ & 342 & 184 & 86 & 100 & 100 & 63 & 0 & 13 \\
\hline Prophet $^{\mathrm{s}}$ & $\mathrm{S}$ & $\mathrm{S}$ & $\mathrm{R}$ & $\mathrm{R}$ & 335 & 204 & 86 & 94 & 94 & 50 & 0 & 6 \\
\hline PX9942595s & $\mathrm{S}$ & $\mathrm{S}$ & $\mathrm{R}$ & $\mathrm{R}$ & 329 & 213 & 86 & 86 & 100 & 63 & 0 & 0 \\
\hline Red Knight ${ }^{s}$ & $\mathrm{~S}$ & $\mathrm{~S}$ & $\mathrm{R}$ & $\mathrm{R}$ & 353 & 283 & 113 & 112 & 100 & 94 & 13 & 25 \\
\hline Revelation $^{\mathrm{s}}$ & $\mathrm{S}$ & $\mathrm{S}$ & $\mathrm{R}$ & $\mathrm{R}$ & 351 & 283 & 95 & 86 & 100 & 88 & 13 & 0 \\
\hline Revolution $^{t}$ & $\mathrm{~S}$ & $\mathrm{R}$ & $\mathrm{R}$ & $\mathrm{R}$ & 326 & 98 & 89 & 101 & 100 & 25 & 0 & 13 \\
\hline Snapper ${ }^{W}$ & $\mathrm{~S}$ & $\mathrm{~S}$ & $\mathrm{R}$ & $\mathrm{S}$ & 368 & 299 & 112 & 106 & 100 & 100 & 19 & 25 \\
\hline \multicolumn{13}{|l|}{$(\text { poblano type })^{\mathrm{x}}$} \\
\hline $\operatorname{LSD}(P=0.05)^{\mathrm{y}}$ & & & & & 44 & 62 & NS & NS & & & & \\
\hline \multicolumn{13}{|l|}{ Experiment 2} \\
\hline Alliance ${ }^{t}$ & $\mathrm{~S}$ & $\mathrm{~S}$ & $\mathrm{R}$ & $\mathrm{R}$ & 371 & 165 & 105 & 104 & 94 & 44 & 6 & 6 \\
\hline Aristotle (pelleted) ${ }^{\mathrm{s}}$ & $\mathrm{S}$ & $\mathrm{R}$ & $\mathrm{R}$ & $\mathrm{R}$ & 389 & 117 & 109 & 90 & 100 & 13 & 6 & 0 \\
\hline Brigadier $^{\mathrm{u}}$ & $\mathrm{S}$ & $\mathrm{S}$ & $\mathrm{R}$ & $\mathrm{R}$ & 405 & 195 & 125 & 106 & 100 & 44 & 25 & 13 \\
\hline Camelot $^{\mathrm{s}}$ & $\mathrm{S}$ & $\mathrm{S}$ & $\mathrm{R}$ & $\mathrm{R}$ & 391 & 173 & 103 & 90 & 100 & 38 & 6 & 0 \\
\hline \multicolumn{13}{|l|}{$(\text { serrano type })^{\mathrm{z}}$} \\
\hline Declaration $^{\mathrm{t}}$ & $\mathrm{S}$ & $\mathrm{R}$ & $\mathrm{R}$ & $\mathrm{R}$ & 255 & 90 & 91 & 90 & 88 & 0 & 0 & 0 \\
\hline Karisma $^{t}$ & $\mathrm{~S}$ & $\mathrm{~S}$ & $\mathrm{R}$ & $\mathrm{R}$ & 369 & 144 & 91 & 107 & 94 & 25 & 0 & 6 \\
\hline NY07-8001z & $\mathrm{R}$ & $\mathrm{R}$ & $\mathrm{R}$ & $\mathrm{R}$ & 126 & 90 & 90 & 90 & 13 & 0 & 0 & 0 \\
\hline NY07-8006 & $\mathrm{R}$ & $\mathrm{R}$ & $\mathrm{R}$ & $\mathrm{R}$ & 90 & 90 & 90 & 90 & 0 & 0 & 0 & 0 \\
\hline NY07-8007z & $\mathrm{R}$ & $\mathrm{R}$ & $\mathrm{R}$ & $\mathrm{R}$ & 90 & 90 & 90 & 90 & 0 & 0 & 0 & 0 \\
\hline Paladin $^{\mathrm{u}}$ & $\mathrm{S}$ & $\mathrm{R}$ & $\mathrm{R}$ & $\mathrm{R}$ & 208 & 90 & 90 & 90 & 44 & 0 & 0 & 0 \\
\hline Red Knights & $\mathrm{S}$ & $\mathrm{S}$ & $\mathrm{S}$ & $\mathrm{R}$ & 368 & 252 & 128 & 128 & 94 & 69 & 25 & 19 \\
\hline Revolution $^{t}$ & $\mathrm{~S}$ & $\mathrm{R}$ & $\mathrm{R}$ & $\mathrm{R}$ & 313 & 90 & 90 & 90 & 88 & 0 & 0 & 0 \\
\hline Snapper ${ }^{w}$ & $\mathrm{~S}$ & $\mathrm{~S}$ & $\mathrm{R}$ & $\mathrm{R}$ & 392 & 216 & 110 & 104 & 100 & 63 & 6 & 6 \\
\hline \multicolumn{5}{|l|}{$\operatorname{LSD}(P=0.05)^{\mathrm{y}}$} & 49 & 55 & NS & NS & & & & \\
\hline \multicolumn{13}{|c|}{$\begin{array}{l}\text { Disease response was determined based on average plant disease score }(1 \text { to } 5 \text { rating scale, } 1=\text { healthy, } 2=\text { minor wilting, } 3=\text { moderate wilting, } 4=\text { sever } \\
\text { wilting, } 5=\text { plant death) at the end of the experiment. If the score was }<2 \text {, the pepper line was considered resistant }(\mathrm{R}) \text {; if the score was } \geq 2 \text {, the pepper lin } \\
\text { was considered susceptible }(\mathrm{S}) \text {. }\end{array}$} \\
\hline \multicolumn{13}{|c|}{ p Area under the disease progress curve (AUDPC) was calculated by using the plant disease score evaluated every 2 days. } \\
\hline \multicolumn{13}{|c|}{ q Potting media was inoculated with $1 \mathrm{~g}$ of prepared millet seed inoculum per plant. } \\
\hline $\mathrm{r}$ Bell pepper line unle & s otherwi & indicate & & & & & & & & & & \\
\hline s Seminis Vegetable $\mathrm{S}$ & eds, St. L & is, MO. & & & & & & & & & & \\
\hline t Harris Moran Seed & ompany, 1 & desto, C & & & & & & & & & & \\
\hline u Syngenta Seeds Inc. & Golden V & ey, MN. & & & & & & & & & & \\
\hline${ }^{v}$ Pepper Research Inc & Belle Gl & e, FL. & & & & & & & & & & \\
\hline${ }^{\mathrm{w}}$ Enza Zaden, Enkhui & en, Nethe & ands. & & & & & & & & & & \\
\hline x Sakata Seeds, Morg. & Hill, CA & & & & & & & & & & & \\
\hline y Least significant diff & rence. & & & & & & & & & & & \\
\hline z Provided hy Cornell & & & & & & & & & & & & \\
\hline
\end{tabular}


to determine relative resistance of pepper lines (29). However, this method could not be used in our study because the resistant standard CM334 was not included in our first experiment. We used a method adapted from Glosier et al., who used a 0 to 5 disease rating scale $(0=$ no symptoms, $1=$ leaf yellowing, $2=$ minor stem necrosis, $3=$ moderate stem necrosis and some leaf wilt, $4=$ severe stem necrosis and severe wilt, $5=$ plant death) and considered plants with an average disease score of $<2$ as resistant (11). Both Sy et al. (29) and Glosier et al. (11) determined physiological races by the patterns in resistant and susceptible pepper lines to specific $P$. capsici isolates. The methods of Sy et al. (29) and Glosier et al. (11) are helpful, but determining if the physiological races are the same among geographic regions is difficult because the statistical methods and cultivars used differed between the two experiments. Also, using the currently acceptable methods, it appears that a high number of physiological races can be determined from a relatively low number of isolates $(11,19,29)$, which would imply that cultivars need to be resistant to several different races. However, this has not been tested under field conditions.

There appeared to be differences in virulence between the $P$. capsici isolates tested and the susceptibility of pepper lines in our study. The pepper isolate used in our study was highly virulent on the crown, roots, and fruits of pepper; however, this does not necessarily indicate that pepper isolates are more virulent than cucurbit isolates. Ristaino found cucurbit isolates were, in some cases, just as virulent on pepper as pepper isolates (24). Polach and Webster (21) observed different levels of virulence

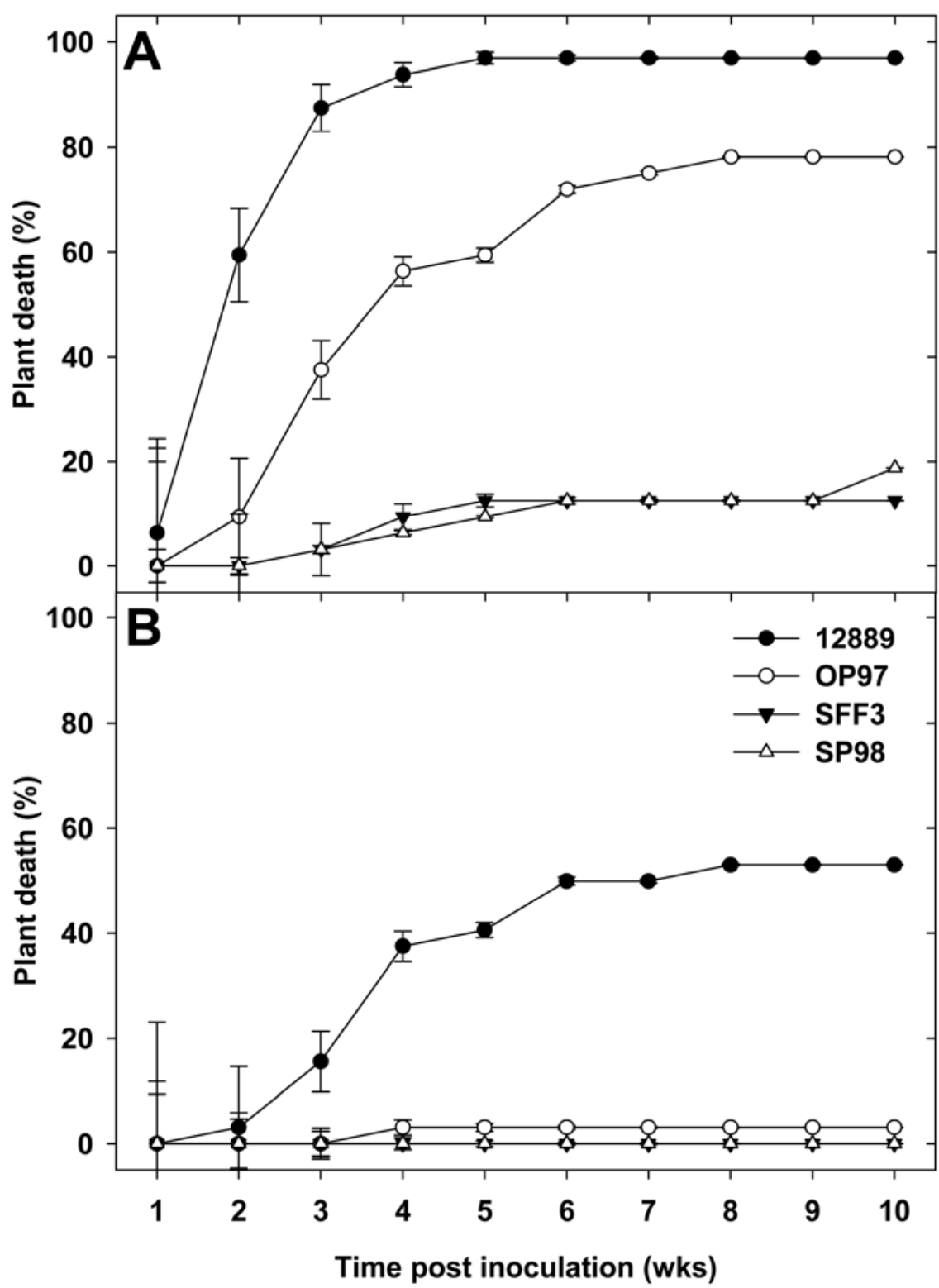

Fig. 2. Plant death (\%) recorded weekly of A, pepper cultivar Red Knight, and $\mathbf{B}$, pepper cultivar Paladin, caused by Phytophthora capsici isolated from pickling cucumber (OP97, SFF3), pumpkin (SP98), and pepper (12889). among $P$. capsici isolates, and others have made similar observations in previous studies with pepper $(11,19)$. However, $P$. capsici isolates 12889, OP97, SP98, and SFF3 did not differ in virulence when inoculated onto Fraser fir seedlings (22), and OP97, SP98, and SFF3 did not differ in virulence on cucumber fruit (8). A recent study with tomato found significant differences in virulence among the $P$. capsici isolates 12889, OP97, SP98, and SFF3 (23) in agreement with the results of this study. Tomato is part of the Solanaceae family and therefore more likely to have resistance mechanisms similar to those of pepper $(32,34)$ than to those of cucurbits or Fraser fir. Differences in incidence of $P$. capsici infection in our study were observed in the fruit screen with isolate 12889 (from pepper) causing more disease than isolate OP97 (from pickling cucumber), which caused more disease than isolate SP98 (from pumpkin). Although significant differences in virulence were observed among the isolates, they cannot be considered different Phytophthora fruit rot races because they caused infection on the fruits of all pepper lines.

Our results indicate that pepper fruits are more susceptible to $P$. capsici than are roots and crowns. Other reports have indicated different levels of resistance exist to foliar blight, stem blight, and root rot of pepper $(14,19,28)$. Also, different mechanisms are responsible for resistance to these three diseases in pepper $(3,19)$. Similarly, potato breeders found plants exhibiting tuber resistance to $P$. infestans did not necessarily have resistance to foliar or vine infection by the same $P$. infestans races $(4,26)$. These results, along with differing physiological races of $P$. capsici, have great implications for pepper breeders. Instead of breeding for resistance to one disease in pepper, breeders must now potentially breed for resistance to four: root rot, fruit rot, stem blight, and foliar blight $(3,19,28)$.

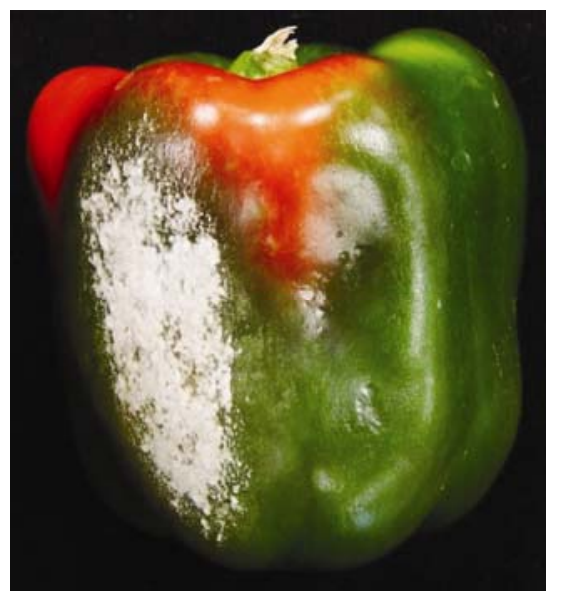

Fig. 3. Pepper fruit $84 \mathrm{~h}$ postinoculation with a $10-\mu \mathrm{l}$ drop of Phytophthora capsici zoospore suspension $\left(1.75 \times 10^{6}\right.$ zoospores $\left./ \mathrm{ml}\right)$. 
Once a small standard set of cultivars and pepper lines is established, a greater number of isolates can be screened to determine those groups of cultivars that may provide the highest level of resistance in a particular geographic region. This information could be pooled across regions, which would help pepper producers manage Phytophthora crown and root rot more effecment of resistant pepper cultivars. Also, producers could consider growing several cultivars in their fields to determine which has the highest level of resistance to local $P$. capsici isolates. This study demonstrates that information from one region may not accurately predict the response of a resistively and further facilitate the develop-

tant cultivar used in another region, including diverse geographic regions within a single state.

\section{ACKNOWLEDGMENTS}

We thank all the members of the Hausbeck lab for their valuable suggestions and help. We especially thank M. Wood for technical assistance. We thank W. Wang for assistance with the statistical analysis, L. Granke, S. Linderman, and B. Webster for editing, and S. Glaspie for greenhouse assistance. This material is based on support provided by the United States Department of Agriculture Cooperative State Research, Education and Extension Service Special Research Grant under Award No. 2006-34572-16902 and 2008-34572-19339 (Phytophthora Research, MI), the Michigan State University Michigan Agriculture Experiment Station Hatch Project 01966 (Phytophthora Research, MI), and the Pickle and Pepper Research Commit-

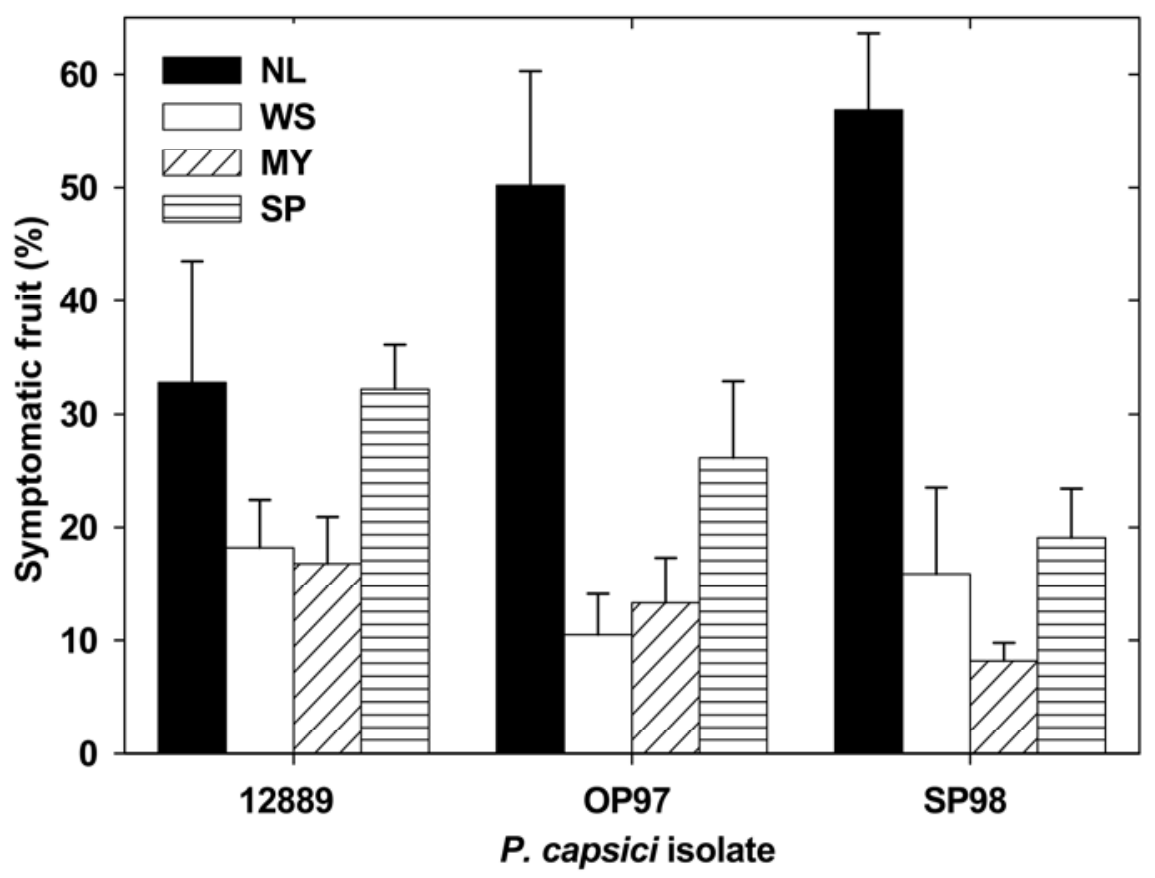

Fig. 4. Pepper fruit (\%) with or without disease symptoms averaged across all pepper lines when inoculated with 10- $\mu$ l drops $\left(1.75 \times 10^{6}\right.$ zoospores $\left./ \mathrm{ml}\right)$ of Phytophthora capsici isolates obtained from pepper (12889), pickling cucumber (OP97), and pumpkin (SP98). NL = no lesion, WS = water-soaking only, MY = mycelial growth and water-soaking, and SP = sporulation, mycelial growth, and watersoaking. tee of Michigan State University, Pickle Packers International, Inc.

\section{LITERATURE CITED}

1. Agrios, G. N. 2005. Plant Pathology. Elsevier Academic Press, USA.

2. Anonymous. 2009. Quick Stats: Agricultural Statistics Data Base, 04.04.2008. U.S. Dep. Agric. Natl. Agric. Stat. Serv. Online publication.

3. Barksdale, T. H., Papavizas, G. C., and Johnston, S. A. 1984. Resistance to foliar blight and crown rot of pepper caused by Phytophthora capsici. Plant Dis. 68:506-509.

4. Bonde, R., Stevenson, F. J., and Clark, C. F. 1940. Resistance of certain potato varieties and seedling progenies to late blight in the tubers. Phytopathology 30:733-748

5. Bosland, P. W., and Lindsey, D. L. 1991. A seedling screen for Phytophthora root rot of pepper, Capsicum annuum. Plant Dis. 75:1048-1050.

6. Café-Filho, A. C., and Duniway, J. M. 1996. Effect of location of drip irrigation emitters and position of Phytophthora capsici infections in roots on Phytophthora root rot of pepper. Phytopathology 86:1364-1369.

7. Erwin, D. C., and Ribeiro, O. K. 1996. Phytophthora Diseases Worldwide. American Phytopathological Society, St. Paul, MN.

8. Gevens, A. J., Ando, K., Lamour, K. H., Grumet, R., and Hausbeck, M. K. 2006. A detached cucumber fruit method to screen for resistance to Phytophthora capsici and effect of fruit age on susceptibility to infection. Plant Dis. 90:1276-1282.

9. Gevens, A. J., Donahoo, R. S., Lamour, K. H., and Hausbeck, M. K. 2008. Characterization of Phytophthora capsici causing foliar and pod blight of snap bean in Michigan. Plant Dis. 92:201-209.

10. Gil Ortega, R. G., Palazon-Espanol, C., and Cuartero-Zueco, J. 1991. Genetics of resistance to Phytophthora capsici in the pepper line 'SCM-334'. Plant Breed. 107:50-55.

11. Glosier, B. R., Ogundiwin, E. A., Sidhu, G. S., Sischo, D. R., and Prince, J. P. 2008. A differential series of pepper (Capsicum annuum) lines delineates fourteen physiological races of Phytophthora capsici. Euphytica 162:23-30.

12. Guerrero-Moreno, A., and Laborde, J. A. 1980. Current status of pepper breeding for resistance to Phytophthora capsici in Mexico. Pages 52-56 in: Synopses Meet Capsicum Working Group Eucarpia, 4th. I.V.T., Wageningen, Netherlands.

13. Hausbeck, M. K., and Lamour, K. H. 2004 Phytophthora capsici on vegetable crops: Re-
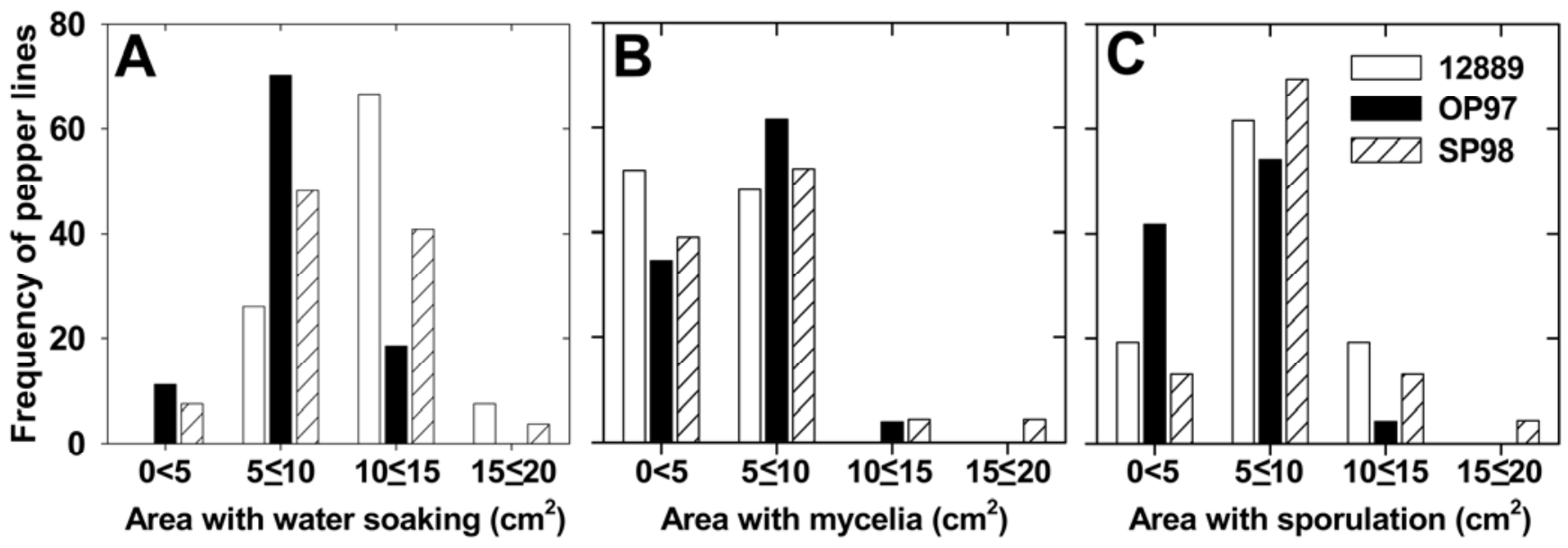

Fig. 5. Area of A, water-soaking, B, mycelial growth, and $\mathbf{C}$, pathogen sporulation on pepper fruit inoculated with $10-\mu l$ drops $\left(1.75 \times 10^{6}\right.$ zoospores/ml) of Phytophthora capsici isolates 12889, OP97, and SP98. Areas were calculated by measuring two diameters perpendicular to each other across the fruit lesion. 
search progress and management challenges. Plant Dis. 88:1292-1303.

14. Hwang, B. K., Kim, Y. J., and Kim, C. H. 1996. Differential interactions of Phytophthora capsici isolates with pepper genotypes at various plant growth stages. Eur. J. Plant Pathol. 102:311-316.

15. Lamour, K. H., and Hausbeck, M. K. 2003. Susceptibility of mefenoxam-treated cucurbits to isolates of Phytophthora capsici sensitive and insensitive to mefenoxam. Plant Dis. 87:920-922.

16. Lefebvre, V., and Palloix, A. 1996. Both epistatic and additive effects of QTLs are involved in polygenic induced resistance to disease: A case study, the interaction pepperPhytophthora capsici Leonian. Theor. Appl. Genet. 93:503-511.

17. Lefebvre, V., Pflieger, S., Thabuis, A., Caranta, C., Blattes, A., Chauvert, J. C., Daubeze, A. M., and Palloix, A. 2002. Towards the saturation the pepper linkage map by alignment of three intraspecific maps including knownfunction genes. Genome 45:839-845.

18. Leonian, L. H. 1922. Stem and fruit blight of chiles caused by Phytophthora capsici sp. Phytopathology 12:401-408.

19. Oelke, L. M., Bosland, P. W., and Steiner, R. 2003. Differentiation of race specific resistance to Phytophthora root rot and foliar blight in Capsicum annuum. J. Am. Soc. Hortic. Sci. 128:213-218.

20. Pflieger, S., Palloix, A., Caranta, C., Blattes, A., and Lefebvre, V. 2001. Defense response genes co-localize with quantitative disease resistance loci in pepper. Theor. Appl. Genet. 103:920-929.
21. Polach, F. J., and Webster, R. K. 1972. Identification of strains and inheritance of pathogenicity in Phytophthora capsici. Phytopathology 62:20-26.

22. Quesada-Ocampo, L. M., Fulbright, D. W., and Hausbeck, M. K. 2009. Susceptibility of Fraser fir to Phytophthora capsici. Plant Dis. 93:135141.

23. Quesada-Ocampo, L. M., and Hausbeck, M. K. 2009. Resistance in tomato and wild relatives to Phytophthora capsici. (Abstr.) Phytopathology 99:S106.

24. Ristaino, J. B. 1990. Intraspecific variation among isolates of Phytophthora capsici from pepper and cucurbit fields in North Carolina. Phytopathology 80:1253-1259.

25. Ristaino, J. B., and Johnston, S. A. 1999. Ecologically based approaches to management of Phytophthora blight on bell pepper. Plant Dis. 83:1080-1089.

26. Rudolf, W., Schaper, P., Ross, H., Baerecke, M., and Torka, M. 1950. The breeding of resistant varieties of potatoes. Am. Potato J. 27:222-235.

27. Shaner, G., and Finney, R. E. 1977. The effect of nitrogen fertilization on the expression of slow mildewing resistance in known wheat. Phytopathology 67:1051-1056.

28. Sy, O., and Bosland, P. W. 2005. Inheritance of Phytophthora stem blight resistance as compared to Phytophthora root rot and foliar blight in Capsicum annuum L. J. Am. Hortic. Sci. 30:75-78.

29. Sy, O., Steiner, R., and Bosland, P. W. 2008. Recombinant inbred line differential identifies race-specific resistance to Phytophthora root rot in Capsicum annuum. Phytopathology
98:867-870.

30. Tamietti, G., and Valentino, D. 2001. Physiological characterization of a population of Phytophthora capsici Leon. from northern Italy. J. Plant Pathol. 83:1101

31. Thabuis, A., Lefebvre, V., Bernard, G., Daubeze, A. M., Phaly, T., Pochard, E., and Palloix, A. 2004. Phenotypic and molecular evaluation of a recurrent selection program for a polygenic resistance to Phytophthora capsici in pepper. Theor. Appl. Genet. 109:342-351.

32. Thabuis, A., Palloix, A., Pflieger, S., Daubeze, A. M., Caranta, C., and Lefebvre, V. 2003. Comparative mapping of Phytophthora resistance loci in pepper germplasm: Evidence for conserved resistance loci across Solanaceae and for a large genetic diversity. Theor. Appl. Genet. 106:1473-1485.

33. Thompkins, C. M., and Tucker, C. M. 1941 Root rot of pepper and pumpkin caused by $P h y$ tophthora capsici. J. Agric. Res. 63:417-427.

34. van Ooijen, G., van den Berg, H. A., Cornelissen, B. J. C., and Takken, F. L. W. 2007. Structure and function of resistance proteins in Solanaceous plants. Annu. Rev. Phytopathol 45:43-72.

35. Walker, S. J., and Bosland, P. W. 1999. Inheritance of Phytophthora root rot and foliar blight resistance in pepper. J. Am. Soc. Hortic. Sci. 124:14-18.

36. Waterhouse, G. 1963. Key to the species of Phytophthora de Bary. Commonwealth Mycological Society, Kew, England.

37. Wyenandt, C. A., and Kline, W. L. 2006. Evaluation of skin separation (silvering) in fruit of bell pepper cultivars. HortScience 40:494 